講演

\title{
ホテル, レストラン, 広告照明†
}

ウィーン市における CIE 大会の会場は, 旧王宮で, 大シャンデリアがさん然と輝いている大広間であった が，その机上の照度は501x しかなかった。国際照明会 議の会場が $501 \mathrm{x}$ とはいささか皮肉の感がした。

ホテル，レストラン，住宅関係は北欧 3 力国が議長と なって会議が開かれたが, 概沉としては, けい光灯が少 しずつ普及してきたこと，そしてそれは特にアメリカに おいて著しいこと，また適正照度は国によって非常に違 うことなどが報告された。

広告照明はハンガリーが議長となり，日本からは投光 照明の報告に岡田喜義博士が当たり, 小生は広告塔を受 け持った。 そして，宣弘社製作の日本の広告塔の 16 ミ リフィルムを映写した所が，満場の大かっさいをあび, 見落とした人たちの要求で琣日 2 度目の上映といら前例 のないことまで行なわれた。なにぶん日本のよらな豪華 な広告塔というものは世界に例のないものであるから， 各国の人を感嘆させたのはむりもない，

最後の閉会式には, 各国の人もだいぶ減り，日本から の委員では尾本博士夫妻, 森博士と小生と 4 人が出席し たが，議長のオーストリアのフィンク氏から，来年もま たきてくれといわれた。しかし，日本は遠いので同じ人 が 2 度来ることは困難だと答えて拈いたが，ヨーロッパ は各国がみな近いので，同じ人が毎回きて，互いに親密 になっていたのはららやましかった。

また，及な夫人同伴で，そうでないのは共産圈と日本 だけだといわれたが，幸い尾本博士夫人が出られたので 面目を施した。

会議の終了後, 約 2 カ月にわたって, 欧州各地の照明 を見学したので，そのうち，ホテル，レストランの照明 ならびに広告照明沉いて報告する。

\section{1． ホテル客室の照明}

第 1 表 客室の照明

\begin{tabular}{|c|c|c|c|c|c|c|c|c|c|}
\hline & & \multirow{2}{*}{$\frac{\text { 灯 }}{\text { その他 }}$} & \multicolumn{2}{|c|}{ ベットランブ } & \multirow[t]{2}{*}{$\begin{array}{l}\text { 床スタ } \\
y \quad F\end{array}$} & \multicolumn{2}{|c|}{$\begin{array}{l}\text { テーブル } \\
\text { ラング }\end{array}$} & \multicolumn{2}{|c|}{ 鏡の照明 } \\
\hline & 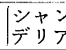 & & せ & 壁灯了 & & $\begin{array}{l}\text { スタ } \\
\text { ソト }\end{array}$ & 檗灯 & $\begin{array}{l}\text { 泋w } \\
\text { 光灯 }\end{array}$ & 電球 \\
\hline 0 & 17 & 8 & 7 & 13 & 4 & 3 & 7 & 2 & 21 \\
\hline
\end{tabular}

$\dagger$ Hotel, Restaurant \& Singboard Illumination.

* 関東学院大学

Vol. 47 No. 12

\section{専門会員関重 広*}

まず，自分が泊まった 25 軲のホテルの客室の照明を 分類してみると第 1 表のよらである.

これからわかることは

（1）ほとんど全部が電球で，けい光灯はごく少ない.

(2) 天井灯にはシャンデリアが多い.

（3） ベッドランプに壁灯が多く，スタンドが少ない。

(4) 床スタンドが案外少ない（最高級ホテルですら 2 軒共なかった).

（5）テーブル用のランプのない所も多い.

次に，高級ホテルと，中，下級ホテルとを比較すると， 高級ホテルは灯数が多く, 古いホテルは豪華なシャンデ リアが天井灯として取り付忛られ，新式のものは，鏡の 照明に明るいけい光灯 ( $40 \mathrm{~W}$ もくは $80 \mathrm{~W}$ の天然色形) がつ村られていた。

下級ホテルでは，一般に灯数が少なく，鏡の照明さえ ない所があって不便で困った。

鏡の照明は従来日本では计い光灯の $10 〜 20 \mathrm{~W}$ が多く, うすぐらくて顔色も血色がわるく見えたが，最近建てら れた高級ホテルは 40〜80W の明るいものが取り付けら れ，この点はよいが，天然色形でないのが惜しい. 10〜 $20 \mathrm{~W}$ の白色や昼光色をつけるくらいなら電球のほらが よい.

泊まった客室の照明器具は全部スケッチして来たが，
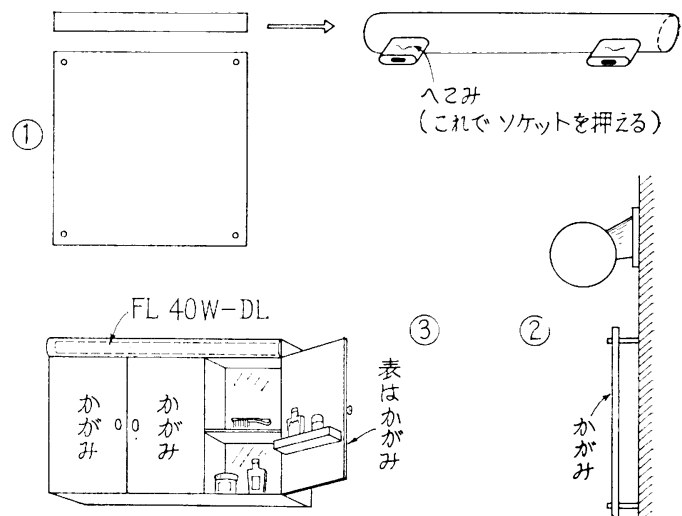

(2)

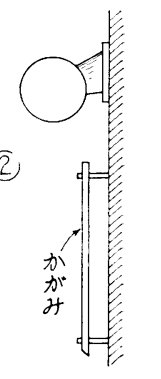

第 1 図 ホテルの鏡の照明例

(1) 側面にソケットをつけ，譬にはめ迈むランプ

(2) 斜めに切つたグローブ用金具

(3) けい光灯をつけたメディシンチェスト 

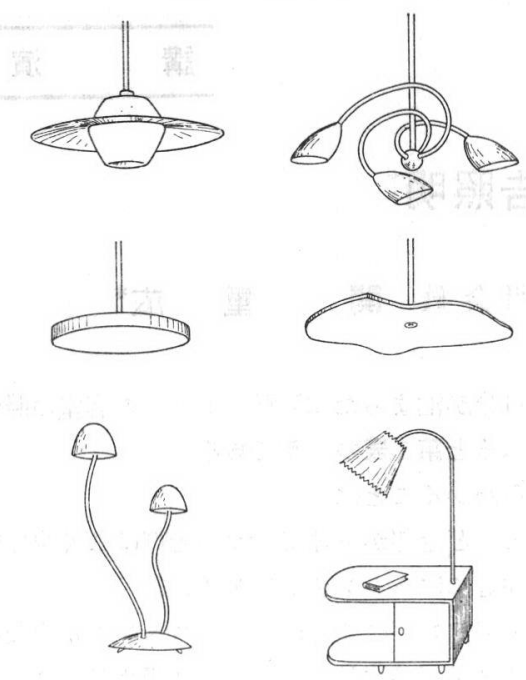

第 2 図珍らしい天井灯と床スタンド

大体古いホテルはクリスタルシャンデリア，新しいホテ ルは新しい形のシャンデリアが多く使われていた．シャ ンデリアにも新しいデザインのものがあるということは 日本でも認識してよいと思う.

客室の照明に電球ばかり使われているのは, 欧州は気 温も低く（南国といわれているイタリアでさ光，北海道 と大体同緯度である), 電球のもつ暖かいふんい気が好 まれるためもあろうし，また一般に保守的で，新しいも のにすぐとびつかない国民性にもよるであろう．

しかし, 電球の欠陌は照度に現われている. 客室の照 明でもデスクの上は少なくとも $200 \mathrm{~lx}$ はほしいのに, これに達しないホテルが大部分であった。テスクランプ だけはけい光灯にして十分の照度がほしい。

次に, ベッドランプに壁灯が案外多かったが，そのス イッチの位置が高く, 起き上がらなければ手の届かない ものが多く不便であった。これは電工がスイッチをつけ るのに，平面図だけを見て，高さに無関心でつけたた好 であろうが，こういう肝心な点が照度とともに案外無雑 作に扱われている.

\section{2. ホテル食堂の照明}

高級ホテルと下級ホテルとの相違は, 食堂のようなパ ブリックスペースの大小に現われている。すなおち高級 ホテルほど食堂は広く, かつ照明も豪華である。一般に シャンデリアが圧倒的で, 古いホテルはクリスタルシャ ンデリア, 新しいホテルでは新しい形のシャンデリアが 用いられていることは客室と同様である.

ここにシャンデリヤといらのは, 必ずしもシャンデリ ヤ本来の意味であるローソク形の電球を上向きに点灯し たものに限らず，多灯式の器具を総称したものである が，その例は第 2 図（右上）と第3図に示されてある.

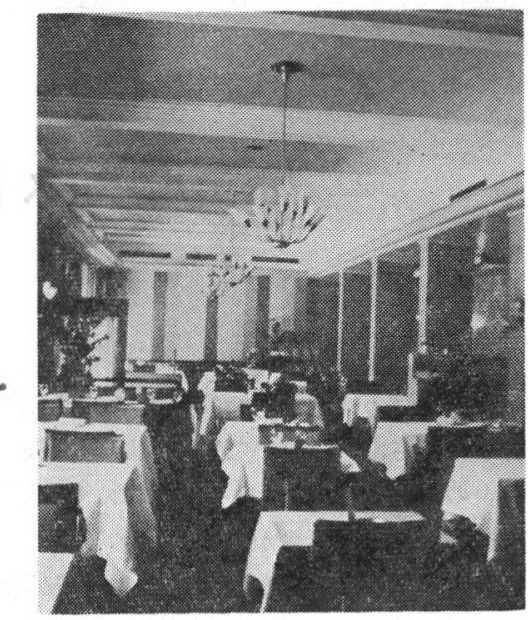

第 3 図 食堂の新椂式シャンデリア

\section{3. レストランの照明}

レストランの照明もホテル食堂と同様であるが，ホテ ルのほうは大体一定しているのに，レストランでは，い ろいろと珍奇な照明を工夫している所もある。中には, 器具の形だけの打もしろさを追って, 照明の実際の要求 に添わないものさえある.

しかし，大体に扒いて，電灯のかさの色を赤や黄にし たり，器具の金属の部分を金色にして暖かさ，楽しさを かもしだすように苦心が払われていて，先の店の外を通 ってガラス空ごしになが姉たとき，いかにも楽しそらに 見光るものが多い，

欧州では店の外の歩道にはみ出して, 椅子テーブルを ならべている所も多いが，こういう所の照明は割に無雑 作でシャンデリアはほとんどないが最近日本によく見ら れる1灯用の新形つり下げ器具もよく用いられている. そして, その器具も白色よりもいろいろと美しい色彩に 富んでいるものが多い.

\section{4. 電気サイン}

電気サインでは日本のようなビル屋上の豪華な広告塔 はない，これは屋根の形が平らでないことにも原因があ ろう。欧州の電気サインの特色を日本と比較してしるせ ば,

（1）一般にビルの壁面に取り付けられているが，隣同 土との配色によく注意されている．新たに取り付けると き，既設のものの色をよく見て，それに調和する色を選 ぶのではないかと思われるくらいである。

(2) ネオンのデザインでは, ローマが最高で, 次はパ リーであるが，両都市共に淡色（白，クリーム，らすい ピンクなど) のものが多い.

（3）赤いネオンはローマには少なく, 北欧に多い。こ れは気温の関係にもよるであるう。パリーには赫いネオ 
ンはないといわれていたが，実際にはシャンゼリゼーに さえかなりある。

(4) スイスは点隇を許さない点では, 戦前の京都のよ らで，さすが静かな風光を売り物にしている観光国らし いが，ネオンの色は，赤や緑の原色のなまなましいもの が多いのは意外である。しかし，これも湖水の対岸から ながめると，水に映った所は中々美しい。

（5）草日本で流行したイルミネーション（電球を建物 の外部に添って連続点灯したもの）が各国にあり，特に オランダ, デンマークに多い. デンマークでは, イルミ ネーションばかりでなく, 普通の電気サインでも, ネオ ンなら簡単にできる文字をわざわざ小電球を連続使用し ているものを所々に見受けるくらいである.

(6) サインを文字でなく商品の形で示しているものも 多く, 特にパリーでは楽局は必ず緑の十字のネオン看板 をつけるのが定石で，これは急病人のためなどにもきわ めて便利である。

（7）日本に多いあんどん看板は欧州には少ないので， 商店街を見渡したときに雨側の建物の感じが暗い。

パリーのエッフェル塔からの夜景はすばらしい，とい らので，観覽料居よりも高いくらであるが，実際に は，ただ街路灯が点々と見光るだけで，東京タワーから のながめとは比較にならない。

\section{5. 投 光 照 明}

日本では自分のビルに投光照明をしている所が多い が，欧州ではこらいう例は少なく，公共建造物すなわ ち, 市庁含, 教会, 銅像, 噴水, 古城, その他の古い観 光対照物などに必ずといえるほど投光照明が施されてい る.

したがって，広告という意味からはややはなれている よらだが，広い意味では，その都市の広告宣伝になるの で、ここにとりあげて見よう。

これらの投光照明で日本と異なる点は次のようであ る.

（1）電灯ははとんど全部白熱電球で，水銀灯は見かけ
なかった、これは, 大がいのものがずっと以前に完成さ れていて，今さら水銀灯に代えなくても，ということも あろらが，細い光柱を使っている所も多く，それには光 源の小さいものがよいわけである.

(2) 照度がきわめて高く，たとえばェッフェル塔のよ らな高い建造物でさ充, 地上 $100 \mathrm{~m}$ の所で的 $200 \mathrm{~lx}$ あ

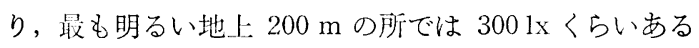
らしかった（このための投光器としては1,500W 用のも のが約 100 灯使われている).

（3）投光器は多く地上のような低い所において，㡺間 目ざわりにならないよらにしてあるものが多く, 特にパ リーでは地面に辰方形の穴を堀り，その中に投光器を設 置し，㡺間はふなをして，その上を歩けるようにしてあ る所屯ある。

(4) 電球からの直接光を防いで, 付近の人にまぶしさ を与えないようにしている。このためには，投光電器前 面に長方形その他の穴を有するしゃ光板を取り付けた り，またはレンズを用いたスポットライトを使用してい る所さえあった。

一般に，不必要な光のしゃ光によく注意が払われてい て,ぞこから光がきているのか気がつかないようなもの がたくさんあったが，こういう細かい点にまで注意がく ばられていることには感心した。

（5）色の変化する照明が案外少ない。日本では広告塔 は当然として, 賃水, ビルなどの照明に色の変化を与え るものがしだいにふえてきているが，欧州では，噴水に わずかながらあるだけで，一般にはほとんどない。これ は，投光照明の対照物が，市庁管とか教会，古城といら よらな色を変化させたりするのが不適当な建物であるこ とが，一つの理由であろら。

欧州の投光照明の特色は大体以上のようであるが，こ のように夜間明るく美しい建造物がたくさん現出するこ とは，夜の観光客を誘致することになる。すなわちそれ らを見るためにその市に一泊するといら観光客もあり， その市の繁栄の一助にもなるわけである。 